Vol.61: e18160644, 2018

http://dx.doi.org/10.1590/1678-4324-2018160644 ISSN 1678-4324 Online Edition
BRAZILIAN ARCHIVES OF BIOLOGY AND TECHNOLOGY

AN INTERNATIONAL JOURNAL

\title{
Arsenic tolerance of Microcystis novacekii (Komárek- Compère, 1974) and its arsenic decontamination potential
}

\author{
Fernanda Aires Guedes Ferreira ${ }^{1 *}$, Maione Wittig Franco ${ }^{\mathbf{1}}$, Dirce Maria De Oliveira ${ }^{\mathbf{1}}$, \\ Sérgia Maria Starling Magalhães ${ }^{2}$, Francisco Antônio Rodrigues Barbosa ${ }^{1}$ \\ ${ }^{1}$ Universidade Federal de Minas Gerais - Instituto de Ciencias Biologicas, Laboratório de Limnologia, \\ Ecotoxicologia e Ecologia Aquática, Belo Horizonte, Minas Gerais, Brasil. ${ }^{2}$ Universidade Federal de Minas Gerais \\ - Farmácia Social, Belo Horizonte, Minas Gerais, Brasil
}

\begin{abstract}
Cyanobacteria possess metallic ion interaction properties that should be explored with the aim of recovering arsenic (As) contaminated areas. Contamination of As is an issue of worldwide concern due to the risk of human chronic intoxication and negative environmental health effects. In this study the potential decontamination of As(III) and As(V) using cyanobacteria cultures was assessed. Microcystis novacekii (Komárek-Compere, 1974) showed normal growth in concentrations of $A s(V)$ similar to those found in natural environments contaminated with As, demonstrating its resistance to As(V). Growth rates gradually decreased upon exposure to high As $(V)$ concentrations from 600 to 5630 mg. $L^{-1}$ while As(III) affected growth from 14.7 - $85.7 \mathrm{mg} . \mathrm{L}^{-1}$. The As(III) EC 50 value (41.0 mg. $\left.L^{-1}\right)$ was 140 -fold lower possibly due to differences in As(III) and As(V) absorption pathways. Upon exposure to $14.7 \mathrm{mg}^{-1} \mathrm{~L}^{-1} \mathrm{As}(\mathrm{III}), 21.2 \%$ of As was removed from culture medium. The absorption capacity $\left(12000 \mathrm{mg}^{\mathrm{kg}} \mathrm{kg}^{-1}\right)$ remained constant with increasing As(III) concentrations in a dose independent effect. The potential of M. novacekii for As decontamination was demonstrated in this study. This microorganism is recommended in As bioremoval studies due to its autotrophicmixotrophic growth, low nutritional requirements and high As(III) absorption capacity.
\end{abstract}

Keywords: arsenic, cyanobacteria, bioaccumulation, toxicity, growth rates.

\footnotetext{
*Author for correspondence: biologaguedes@gmail.com
} 


\section{INTRODUCTION}

Arsenic (As) is an element that occurs in natural waters ranging from typical concentrations less than $10 \mu \mathrm{g} . \mathrm{L}^{-1}$ to values above $50 \mu \mathrm{g} . \mathrm{L}^{-1}$ in arseniferous groundwater ${ }^{1}$. Anthropogenic dispersal of this toxic element is mostly a result of water drainage in mining areas in arseniferous deposits ${ }^{2}$ or when water from aquifers with high concentrations of dissolved As is used for public supply ${ }^{3}$. The risk of As exposure is an issue of worldwide concern ${ }^{1,4}$. Chronic intoxication by this element has been reported in several countries (e. g. Bangladesh, Vietnam, China, Argentina, Chile) where As in water exceeds safety limits in some localities ${ }^{5,6,7}$. On the aquatic ecosystem As pollution can affect the equilibrium and coexistence of aquatic organisms. Furthermore, the capacity of As accumulation by aquatic primary producers is determinant for its biomagnification in the trophic chain ${ }^{8}$.

Using microorganisms as a tool for removal of contaminants such as metals and metalloids is a low-cost process known as bioremediation ${ }^{9}$. Bioremediation technologies have a promising potential to contribute eco-friendly manner. These comprise high-efficiency techniques for heave metal removal in from dilute solutions, in addition, they could provide metal recovery ${ }^{10}$. The accumulation and concentration of pollutants from aqueous solutions by the use of biological materials [such as aquatic macrophytes biomass ${ }^{11,12,13}$ or microbial biomass ${ }^{14,15,16}$ ], facilitating the recovery and/or environmentally acceptable disposal of the pollutant is termed as "bioremoval" 17.

The possibility of using clean technologies for environmental decontamination has spurred the search for resistant organisms that are capable of biotransforming toxic elements such as As. The possibility of using clean technologies for environmental decontamination has spurred the search for resistant organisms that are capable of biotransforming toxic elements such as As ${ }^{18}$. Arsenic metabolism by cyanobacteria has mainly been studied in water-bloom-forming species from eutrophic lakes $19,20,21$.

Cyanobacteria usually dominate in waters contaminated with As ${ }^{21}$. These mixotrophic organisms occupy a unique taxonomic position, combining autotrophic metabolism, common to eukaryotic plant cells, with a heterotrophic metabolic system proper to bacteria ${ }^{22}$. Their capacity to tolerate adverse conditions is due to adaptive characteristics such as nitrogen fixation, chromatic adaptation and nutrient storage in cytoplasmic inclusions ${ }^{23}$. All these features makes cyanobacteria an interesting group to study its potential of As immobilization and water decontamination.

The cyanobacterium Microcystis novacekii (Komárek - Compère, 1974) was selected for this study for its wide environmental distribution and for being able to produce a mucilaginous sheath with a relevant role on metal adsorption ${ }^{24,25}$. The Microcystis genus is cosmopolitan and commonly found in eutrophic lakes. However, studies of $M$. novacekii on toxicity and accumulation of As are not found in the literature. Therefore, the aim of this study was to evaluate As(III) and As(V) toxicity for M. novacekii and its potential for As decontamination in culture medium in laboratory conditions. The decontamination of As by M. novacekii may indicate the relevant role of this organism in As removal from aquatic ecosystems and its potential to mitigate this major source of environmental impacts worldwide.

\section{MATERIALS AND METHODS}

\section{Cyanobacteria culturing}

M. novacekii was isolated from water samples collected at Dom Helvécio Lake (1946'419"S; $42^{\circ} 35^{\prime} 595^{\prime \prime}$ ), located in the Rio Doce State Park, the largest remnant of the Atlantic Forest in the State of Minas Gerais, Brazil. The cyanobacteria strain has been maintained in the algae culture bank in the Laboratory of Limnology, Ecotoxicology and Aquatic Ecology of the Universidade Federal de Minas Gerais.

\section{Toxicity and As bioaccumulation experiments}

M. novacekii was cultivated in Acibenzolar-S-Methyl medium (ASM-1) prepared with ultrapure water (Milli-Q), modified by the addition of 3-(N-morpholino) propane sulfonic acid buffer (Sigma-Aldrich, St. Louis, MO, USA) (750mg.L $\mathrm{L}^{-1}$ ) and adjusted to $\mathrm{pH} 7$.

Cultures $(150 \mathrm{~mL})$ were prepared in $250 \mathrm{~mL}$ Erlenmeyer flasks, under continuous light with a white cold fluorescent lamp $\left(60 \mu \mathrm{mol} \cdot \mathrm{m}^{-2} \cdot \mathrm{s}^{-1}\right)$ and constant agitation $(70 \mathrm{rpm})$ with a rotary 
agitator (Marconi 140, Piracicaba, SP, Brazil) in temperature of $20 \pm 1^{\circ} \mathrm{C}$. The salts disodium hydrogen arsenate heptahydrate $\left(\mathrm{Na}_{2} \mathrm{HAsO}_{4} \cdot 7 \mathrm{H}_{2} \mathrm{O}\right)$ and sodium (meta) arsenite $\left(\mathrm{NaAsO}_{2}\right)$ (Sigma-Aldrich, St. Louis, MO, USA) were used to prepare stock solutions in concentration of $15000 \mathrm{mg} . \mathrm{L}^{-1}$ of $\mathrm{As}(\mathrm{V})$ and $10000 \mathrm{mg} . \mathrm{L}^{-1}$ of $\mathrm{As}(\mathrm{III})$, respectively, which were added to $150 \mathrm{~mL}$ of $M$. novacekii culture in $\log$ phase with a cell density of $10^{6}$ cells. $\mathrm{mL}^{-1}$ to obtain two concentrations series: 0.0, 0.8, 8.0 and $80.0 \mathrm{mg} . \mathrm{L}^{-1}$ of As (V) (series A) and 0.0, 600, 1050, 1840, 3220 and $5630 \mathrm{mg} . \mathrm{L}^{-1}$ of As (V) (series B). For As(III) the series of final concentrations was 0.0, 14.7, 26.5, 47.6 and $85.7 \mathrm{mg} . \mathrm{L}^{-1}$. All experiments were performed in triplicate. The effective concentration of $\mathrm{As}(\mathrm{III})$ and $\mathrm{As}(\mathrm{V})$ that led to $50 \%$ of growth inhibition $\left(\mathrm{EC}_{50}\right)$ for $M$. novacekii was determined according to OECD 201 protocol. The As concentrations were determined in previous tests arranged in geometric series as recommended in $\mathrm{EC}_{50}$ tests ${ }^{26}$.

\section{Analytical procedures}

After exposure to As for 0, 96, and $192 \mathrm{~h}$, aliquots of $10 \mathrm{~mL}$ cultures from the experiment previously described were centrifuged (Sigma $4 \mathrm{k} 15$, Germany) at $3000 \mathrm{rpm}$ for $15 \mathrm{~min}$, at $15^{\circ} \mathrm{C}$. The supernatant were transferred to new tubes, the $\mathrm{pH}$ was adjusted to 2.0 with 1 mol. $\mathrm{L}^{-1} \mathrm{HCl}$ (37\%, Merck KGaA, Darmstadt, Germany) and the aliquots were stored at $4^{\circ} \mathrm{C}$ until further analysis ${ }^{27}$. The pellets were re-suspended in culture medium and rinsed three times with deionised water, followed by mineralization in teflon vessels with $3 \mathrm{~mL} \mathrm{HNO}_{3}(65 \%$, SigmaAldrich, St. Louis, MO, USA) and $1 \mathrm{~mL}$ hydrogen peroxide 30\% (Sigma-Aldrich, Buchs, Germany) in microwave oven (ETHOS 1-Advanced microwave digestion system/Model Milstone) at $200^{\circ} \mathrm{C}$ and 45 bar for $30 \mathrm{~min}$. After cooling to room temperature the final volume was adjusted with water to $25 \mathrm{~mL}$. As concentrations were determined in the cyanobacteria biomass (pellets) and also in the supernatant to quantify the amount of As remaining in the culture medium. The analysis were performed by inductively coupled plasma optical emission spectroscopy, optima 4300 DV Perkin Elmer, Shelton, USA.

\section{Adsorption of As(III)}

To evaluate As(III) adsorption by cyanobacteria cell wall, a new experiment in shorter period of exposure $(2 \mathrm{~h}$ ) was carried out. Aliquots of $100 \mathrm{~mL}$ of the culture in the logarithmic growth phase $\left(10^{6}\right.$ cell. $\left.\mathrm{mL}^{-1}\right)$ were prepared in the same condition described (subsection: Toxicity and As bioaccumulation experiments) were exposed to As(III) in a shorter period of time $(2 \mathrm{~h})$ at concentrations of 2.5, 5.0, 7.5, 10.0, 12.5 and $15.0 \mathrm{mg} . \mathrm{L}^{-1}$. Total As concentrations in supernatants and pellets were determined as described (Analytical procedures). Only As(III) adsorption experiments were performed due to the higher As(III) removal capacity from the culture medium compared to $\mathrm{As}(\mathrm{V})$.

\section{Data analysis}

Growth rates were calculated according to the following equation:

$$
\mu_{i-j}=\ln X_{j}-\ln X_{i} /\left(t_{j}-t i\right) d a y^{-1}
$$

Where: $\mu$ is the average specific growth rate from the time $i$ to $j$ in days

$\mathrm{X}_{i}$ is $\mathrm{n}^{\circ}$ of cells $\mathrm{mL}^{-1}$ at time $\mathrm{i}$.

$\mathrm{X}_{j}$ is $\mathrm{n}^{\circ}$ of cells $\mathrm{mL}^{-1}$ at time $\mathrm{j}$.

Growth inhibition was obtained from the equation:

$$
\% I_{r}=\left[\left(\mu_{c}-\mu_{t}\right) / \mu_{c}\right] \times 100
$$

Where: $\% \mathrm{I}_{r}$ is the percentage of inhibition of the specific growth rate $\mu_{c}$ is the average growth rate in the control group.

$\mu_{t}$ is the average growth rate in replicas of the tests.

The $\mathrm{As}(\mathrm{V})$ and $\mathrm{As}(\mathrm{III})$ bioaccumulation were calculated by equation:

$$
\% \mathrm{As}_{b}=100-\frac{\operatorname{As}(X i)-\operatorname{As}(X m)}{\operatorname{As}(X i)} \times 100
$$

Where: $\% A s_{b}$ is the percentage of arsenic bioaccumulated by the cyanobacteria biomass; $\mathrm{As}(\mathrm{X} i)$ is the arithmetic mean of arsenic concentration added to the aqueous medium at time $\mathrm{i}$; 
$\mathrm{As}(\mathrm{Xm})$ is the arithmetic mean concentration of arsenic found in the cell biomass after a period of time.

The $\mathrm{EC}_{50}$ for $\mathrm{As}(\mathrm{V})$ and $\mathrm{As}(\mathrm{III})$ were calculated by linear regression equation:

$y=-142.3+22.2 x$ and $y=-145.0+52.5 x$, respectively. The homogeneity of variance was tested using Levene's test.

Growth rates in each concentration were compared to control into the same As(III) or As(V) geometric series by a one-way analysis of co-variance (ANCOVA). Differences were considered significant when $\mathrm{p}<0.05$. The analyses were performed in the software Statistica 8.

\section{RESULTS}

\section{$\operatorname{As}($ III) and As(V) toxicity}

At concentrations of 0.08 to $80.0 \mathrm{mg} . \mathrm{L}^{-1}$ (series A) As(V) did not affect the growth rates of $M$. novacekii $(\mathrm{p}>0.05)$ (Figure 1a). It is important to reinforce that these concentrations are similar to those found in water contaminated with $\mathrm{As}(\mathrm{V})$. At concentrations of 600 to $5630 \mathrm{mg} . \mathrm{L}^{-1}$ (series B) $\mathrm{As}(\mathrm{V})$ growth decrease, due to the As toxicity what can be observed at concentrations higher than 1050 mg.L $\mathrm{L}^{-1}(\mathrm{p}<0.05)$ (Figure 1b). Experimental conditions were the same in both series. $M$. novacekii growth decreased significantly when exposed to As(III) (47.6 and $85.7 \mathrm{mg} . \mathrm{L}^{-1}$ ). Significant growth reduction started at $47.6 \mathrm{mg} \cdot \mathrm{L}^{-1}(\mathrm{p}<0.05)$ markedly after the first $24 \mathrm{~h}$ followed by a gradual recovery after 48 h (Figure 1c).

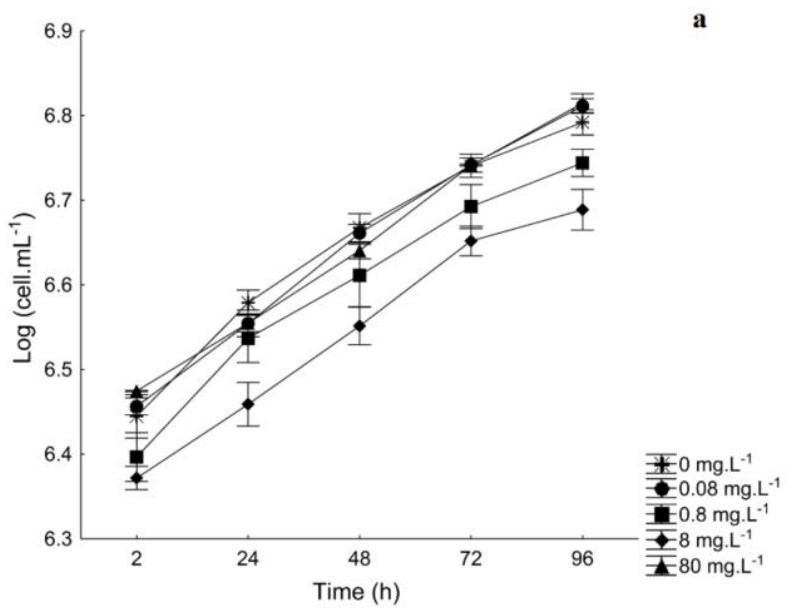



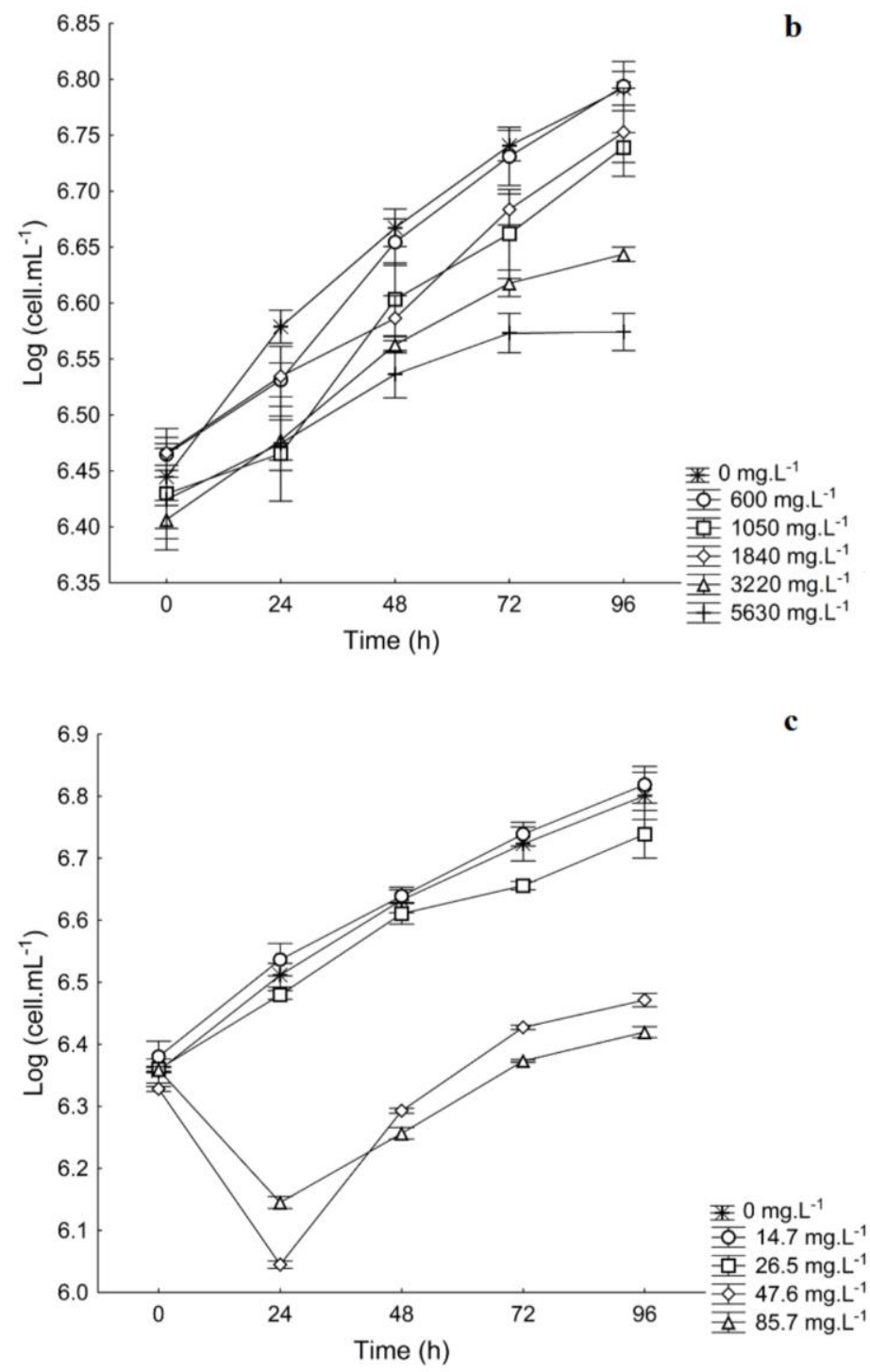

Figure 1. Growth of M. novacekii after 96 h of exposure to As(V); a, series A: 0 to 80.0 mg.L-1; b, series B:0 to 5630 mg.L-1; c, As(III) 0 to 85.7 mg.L-1.

The acute toxicity tests showed that the concentration of $\mathrm{As}(\mathrm{V})$ that effectively reduced the growth rate by $50 \%\left(\mathrm{EC}_{50}\right)$ was $5810 \mathrm{mg} . \mathrm{L}^{-1}$ (Fig. 2a). While the $\mathrm{EC}_{50}$ for As(III) was 41.0 mg. $\mathrm{L}^{-1}$ (Fig. 2b). The concentrations of $\mathrm{As}(\mathrm{III})$ or $\mathrm{As}(\mathrm{V})$ in the supernatant remained constant during the toxicity test period $(96 \mathrm{~h})$. 

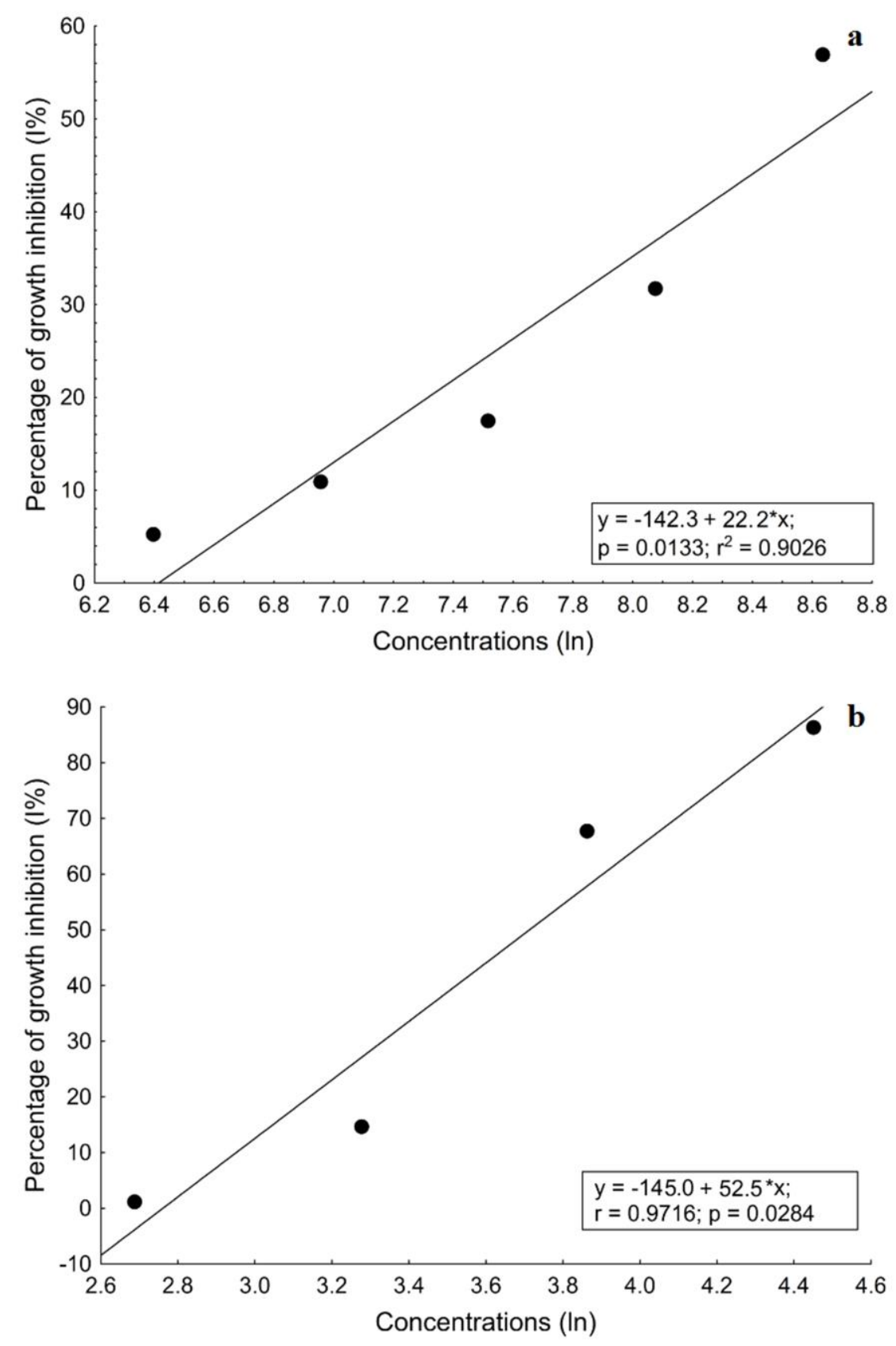

Figure 2. Percentage of growth inhibition for M. novacekii after $96 \mathrm{~h}$ of exposure to $\mathrm{As}(\mathrm{V})$ (a) or $\mathrm{As}(\mathrm{III})$ (b) at increasing concentrations.

\section{Bioaccumulation of As by $M$. novacekii}

Table 1 gives a final balance (\%) after $192 \mathrm{~h}$ of $\mathrm{As}(\mathrm{V})$ or $\mathrm{As}(\mathrm{III})$ added to cultures. The As(V) in biomass $\left(\mathrm{mg} \cdot \mathrm{kg}^{-1}\right)$ increased with the concentrations of As in the culture medium reaching a maximum of $22500 \mathrm{mg} \cdot \mathrm{kg}^{-1}$. However, after $192 \mathrm{~h}$, the initial As concentration in culture medium was very high compared to the absolute amount of As removed by the biomass and, therefore more than $97 \%$ of the initial As concentration remained in culture medium. As(V) in $M$.

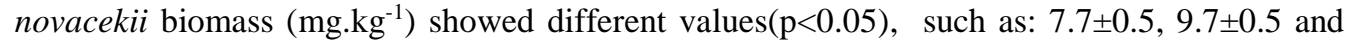
$22.5 \pm 5.0 \mathrm{mg} . \mathrm{kg}^{-1}$ in the three highest concentrations $\left(1840,3220\right.$ and $\left.5630 \mathrm{mg} . \mathrm{L}^{-1}\right)$, respectively. Otherwise, at the lowest concentration tested $\left(0.08 \mathrm{mg} \cdot \mathrm{L}^{-1}\right), 12 \%$ of the $\mathrm{As}(\mathrm{V})$ in culture medium was removed, with bioaccumulation of $40 \pm 20 \mathrm{mg} \cdot \mathrm{kg}^{-1}$ in $M$. novacekii biomass. 
The As(III) maximum removal from the culture medium was $21 \%$ after exposure to $14.7 \mathrm{mg}$. $\mathrm{L}^{-}$ ${ }^{1}$, indicating that $M$. novacekii has a higher decontamination potential for As(III) than As(V). Increasing concentrations of As(III) from 14.7 to $85.7 \mathrm{mg} . \mathrm{L}^{-1}$ did not affect the decontamination of the metalloid by the cyanobacteria, which remained between $12600 \pm 200$ and $12900 \pm 200$ mg.kg-1 As(III) in biomass of M. novacekii, however those concentrations adversely affected the growth of the cyanobacteria.

Table 1. Initial As concentrations (mg.L $\mathrm{L}^{-1}$ ) and final balances (\%) after $192 \mathrm{~h}$ of As(V) or As(III) added to cultures.

\begin{tabular}{|c|c|c|c|c|c|}
\hline \multicolumn{2}{|c|}{ Nominal $[\mathrm{As}]^{\mathrm{a}}$} & \multirow{2}{*}{$\begin{array}{l}\text { Actual initial }[\mathbf{A s}]^{\mathbf{b}} \\
0.07 \pm 0.02\end{array}$} & \multirow{2}{*}{$\begin{array}{l}\text { As }(\%) \text { removed } \\
\text { by the biomass } \\
12.1\end{array}$} & \multirow{2}{*}{$\begin{array}{l}\text { As remaining in } \\
\text { the culture } \\
\text { medium }(\%)\end{array}$} & \multirow{2}{*}{$\begin{array}{l}\text { [As] in biomass } \\
\left(\mathbf{m g}^{\left.-k^{-1}\right)}\right. \\
40 \pm 20\end{array}$} \\
\hline \multirow{9}{*}{$\operatorname{As}(\mathrm{V})$} & 0.08 & & & & \\
\hline & 0.8 & $0.8 \pm 0.01$ & 2.0 & 98.0 & $60 \pm 20$ \\
\hline & 8.0 & $8.6 \pm 0.02$ & 0.5 & 98.8 & $180 \pm 30$ \\
\hline & 80.0 & $79.6 \pm 7.0$ & 0.8 & 97.8 & $2390 \pm 90$ \\
\hline & 600.0 & $597 \pm 10$ & 0.7 & 97.5 & $17800 \pm 7300$ \\
\hline & 1050.0 & $1038 \pm 23$ & 0.4 & 97.6 & $17900 \pm 1800$ \\
\hline & 1840 & $1857 \pm 61$ & 0.1 & 97.9 & $7700 \pm 500$ \\
\hline & 3220 & $3386 \pm 100$ & 0.1 & 97.8 & $9700 \pm 500$ \\
\hline & 5630 & $5790 \pm 190$ & 0.1 & 97.9 & $22500 \pm 5000$ \\
\hline \multirow{4}{*}{$\mathrm{As}(\mathrm{III})$} & 14.7 & $14.8 \pm 0.3$ & 21.2 & 76.6 & $12600 \pm 200$ \\
\hline & 26.5 & $28.4 \pm 0.4$ & 11.4 & 88.4 & $13000 \pm 500$ \\
\hline & 47.6 & $49.9 \pm 1.0$ & 6.4 & 92.1 & $12700 \pm 200$ \\
\hline & 85.7 & $105.6 \pm 0.3$ & 3.1 & 93.3 & $12900 \pm 200$ \\
\hline
\end{tabular}

${ }^{\mathrm{a}}$ Concentration expected.

bConcentration measured.

Values in column 1 and 2 are means \pm standard errors.

Adsorption of $\mathbf{A s}(\mathrm{III})$ in cell surface of $M$. novacekii

After $2 \mathrm{~h}$ of exposure to As(III) (Table 2) $440 \mathrm{mg} \cdot \mathrm{kg}^{-1}$ was adsorbed at the maximum concentration of $15 \mathrm{mg} . \mathrm{L}^{-1}$. This indicates that most of the As fraction removed from the culture medium after $192 \mathrm{~h}$ (showed in Table 1) was not physically attached to the cyanobacteria cell wall but has been bioaccumulated as demonstrated in Table 2 .

$\underline{\text { Table 2. As(III) adsorbed by M. novacekii biomass after } 2 \mathrm{~h} \text { of exposure. }}$

\begin{tabular}{ll}
\hline Tests $\left(\mathbf{m g . L}^{-\mathbf{1}}\right)$ & As in biomass $\left(\mathbf{m g . k g}^{-1}\right)$ \\
\hline 2.5 & 210 \\
5.0 & 260 \\
7.5 & 310 \\
10.0 & 330 \\
12.5 & 350 \\
15.0 & 440 \\
\hline
\end{tabular}




\section{DISCUSSION}

The $\mathrm{EC}_{50}$ for $\mathrm{As}(\mathrm{V})$ was 140-fold higher than $\mathrm{EC}_{50}$ for $\mathrm{As}(\mathrm{III})$ for $M$. novacekii (Fig. 2). The high differences in the $\mathrm{As}(\mathrm{III})$ and $\mathrm{As}(\mathrm{V})$ toxicity reported in this study corroborate those found with other cyanobacteria species. Anabaena doliolum presented $\mathrm{EC}_{50}$ values of $4345 \mathrm{mg} . \mathrm{L}^{-1}$ for As(V) and $824.12 \mathrm{mg} . \mathrm{L}^{-1}$ for $\mathrm{As}(\mathrm{III})^{28}$. The growth rate of $M$. aeruginosa started to decrease at concentrations higher than $0.75 \mathrm{mg} . \mathrm{L}^{-1}$ of $\mathrm{As}(\mathrm{III})$ and $75 \mathrm{mg} . \mathrm{L}^{-1}$ of $\mathrm{As}(\mathrm{V})^{29}$. The sensitivity to As varies greatly with As oxidation state and also with the cyanobacteria species, suggesting the potential effects of this element on the selection of species resistant to As in contaminated environments.

A decrease in growth rates and subsequent recovery was observed during the first $24 \mathrm{~h}$ markedly at $\mathrm{As}$ (III) concentrations above $40 \mathrm{mg} . \mathrm{L}^{-1}$ (Fig. 1c). This is very likely an adaptive behavior which allows acclimation in the presence of the toxic agent. This behavior was also observed in experiments using Anabaena sp. PCC7120 under As stress together with reduction in carbon fixation, nitrogenase activity and chlorophyll content ${ }^{30}$. It is known that intracellular As(III) increases the concentration of reactive oxygen species without stimulating the antioxidant system in cyanobacteria, resulting in toxic effects ${ }^{28}$. The effects of extracellular As(III) on cell membrane integrity are so far poorly investigated. $M$. novacekii displayed capacity for adaptation to $\mathrm{As}(\mathrm{III})$ and $\mathrm{As}(\mathrm{V})$ and therefore, this organism has the potential to dominate environments contaminated with this metalloid.

Various As chemical species can be found in the aquatic environment as a result of biotransformation by microorganisms ${ }^{15}$. As( $(V)$ generally predominates in water under aerobic conditions ${ }^{1}$. Therefore, the effects of a wide range of $\mathrm{As}(\mathrm{V})$ concentrations near environmental levels on cyanobacteria growth were evaluated. In series A, growth inhibition was not observed (Fig. 1a) possibly because As was not absorbed at levels sufficient to disrupt cell metabolism and most of the As remained in culture medium (Table 1). This indicates a low probability of $\mathrm{As}(\mathrm{V})$ bioaccumulation in the food chain compared to other toxic elements. Rzymski et al., $(2014)^{31}$ observed in $M$. aeruginosa a bioaccumulation of $87.3 \%$ and $90.1 \%$ when $20 \mathrm{mg}^{-\mathrm{L}^{-1}}$ of $\mathrm{Cd}$ and $\mathrm{Pb}$ where add to culture medium.

The present study verifies the theory that the removal of As from culture medium is dependent on its chemical species as shown in Table 1. As(III) and As(V) are taken up via different transmembrane transporters. As(III) may enter the cell via aquaglyceroporins a family of proteins also present in cyanobacteria responsible for the uptake of glycerol ${ }^{32,33,34}$. As(V) competes for the phosphate transporter ${ }^{20,35}$ when in the culture medium $\mathrm{PO}_{4}$ is present in the initial concentration of $16.6 \mathrm{mg} \mathrm{L}^{-1}$. M. novacekii displayed potential to uptake $12000 \mathrm{mg} \cdot \mathrm{kg}^{-1}$ of As(III) after exposure to a concentration range from 14.7 to $85.7 \mathrm{mg} \cdot \mathrm{L}^{-1}$. Whereas in the $\mathrm{As}(\mathrm{V})$ concentration range 0.08 to $80.0 \mathrm{mg} . \mathrm{L}^{-1}$, the maximum As absorption was $2390 \mathrm{mg} \cdot \mathrm{kg}^{-1}$. Interestingly, the intracellular As level remained constant with increasing As(III) concentration in culture medium revealing a saturation of absorption capacity. A similar saturation process was also observed in mosses with increasing supply of cationic metals in the medium ${ }^{36}$. To our knowledge, the saturation of As(III) uptake is demonstrated for the first time using a cyanobacteria (M. novacekii) as a test organism.

Biosorption is a physical process that in general reaches equilibrium time in less than 2 hours as demonstrated using cyanobacteria biomass to remove $\mathrm{Cr}^{37}$ and $\mathrm{Sb}^{38}$. After 2 hours of exposure to As(III), the amount of As in M. novacekii biomass was much lower compared to the amount accumulated after $192 \mathrm{~h}$ (Table 1) indicating that the process of As bioaccumulation is not physical but may involve changes in gene expression, as demonstrated in Anabaena sp. PCC7120 after As exposure ${ }^{30}$. Ion exchange is the principal process of As(III) adsorption which is influenced by the As concentration, contact time, $\mathrm{pH}$ of aqueous medium ${ }^{39}$ and by other elements previously adsorbed to the biomass such as iron ${ }^{40}$. Intracellular As can be biotransformed in different chemical species. As(V) can be reduced to As(III) and then immobilized by interaction with sulfhydryl groups, methylated or excreted 17, 30,33,41. Membrane transport and intracellular immobilization are likely to be the mechanisms primarily involved in As absorption by $M$. novacekii.

The development of technological strategies for monitoring and restoration of ecosystems contaminated by As has become a challenge for environmental scientists. In the present study, the adaptation of the cyanobacterium $M$. novacekii to high As concentration and its capacity to accumulate As was demonstrated. These findings encourage using this species in processes of 
As immobilization in waste water, especially As(III), due to its higher absorption capacity compared to $\mathrm{As}(\mathrm{V})$. As water decontamination using M. novacekii is worth to be studied in conditions that favour its application in processes of bio-removal of metals from contaminated waters including wastewaters.

\section{CONCLUSION}

The present study verifies the theory that the removal of As from culture medium is dependent on its chemical species. M. novacekii presented higher efficiency of As(III) removal (21.2\%) from culture medium upon exposure to $14.7 \mathrm{mg} . \mathrm{L}^{-1}$. The bioaccumulation capacity (12000 mg. $\mathrm{kg}^{-1}$ ) remained constant with increasing As(III) concentrations in a dose independent effect. The process of As(III) bioaccumulation is not physical but may involve changes in gene expression. As(V) toxicity was verified in concentrations 140-fold higher compared to As(III), possibly due to the lower As(V) uptake in M. novacekii cells what indicates lower probability of $\mathrm{As}(\mathrm{V})$ bioaccumulation in the food chain. This microorganism is recommended in As decontamination studies due to its autotrophic/mixotrophic growth, low nutritional requirements in addition to its high As(III) decontamination capacity.

\section{ACKNOWLEDGEMENTS}

This work was supported by the Instituto Nacional de Ciência e Tecnologia - Recursos Minerais, Água e Biodiversidade (INCT-Acqua) under Grant No. 573945/2008-0; Fundação de Amparo à Pesquisa do Estado de Minas Gerais (FAPEMIG) under Grant No APQ-00082-09; Coordenação de Aperfeiçoamento de Pessoal de Nível Superior (CAPES) for the scholarships. We also thanks the Pró- Reitoria de Pesquisa-PRPq of Universidade Federal de Minas Gerais for providing funds for the English text editing.

\section{REFERENCES}

1. Smedley PL, Kinniburgh DG. A review of the source, behaviour and distribution of arsenic in natural waters. Appl Geochem. 2002; 17: 517-568. doi:10.1016/S0883-2927(02)00018-5.

2. Garelick H, Jones H, Dybowska A, Valsami-Jones E. Arsenic Pollution Sources. Rev Environ Contam T. 2008; 197: 17-60. doi:10.1007/978-0-387-79284-2_2.

3. Choudhury I, Ahmed KM, Hasan M, Mozumder MRH, Knappett PSK, Ellis T, Van GA. Evidence for elevated levels of arsenic in public wells of Bangladesh due to improper installation. Ground water. 2016; 1: 1-7. doi:10.1111/gwat.12417.

4. Matschullat J, Borba RP, Deschamps E, Ribeiro FB, Gabrio T, Schwenk M. Human and Environmental Contamination in Iron Quadrangle, Brazil. Appl Geochem. 2000; 15: 181190. doi: 10.1016/S0883-2927(99)00039-6.

5. Smith AH, Lingas EO, Rahman M. Contamination of Drinking-Water by Arsenic in Bangladesh: A Public Health Emergency. B World Health Organ. 2000; 78(9): 1093-103. PMCID: PMC2560840.

6. Ning Z, Lobdell DT, Kwok RK, Liu Z, Zhang S, Ma C, Riediker M, Mumford JL. Residential Exposure to Drinking Water Arsenic in Inner Mongolia, China. Toxicol Appl Pharm. 2007; 222(3): 351-356. doi:10.1016/j.taap.2007.02.012.

7. Bundschuh J, Litter MI, Parvez F, Román-Ross G, Nicolli HB, Jean JS et al. One century of arsenic exposure in Latin America: A review of history and occurrence from 14 countries. Sci Total Environ. 2012; 429: 2-35. doi: 10.1016/j.scitotenv.2011.06.024.

8. Rahman MA, Hasegawa H, Lim RP. Bioaccumulation, biotransformation and trophic transfer of arsenic in the aquatic food chain. Environ res. 2012; 116: 118-135. doi:10.1016/j.envres.2012.03.014.

9. Arief VO, Trilestari K, Sunarso J, Indraswati N, Ismadji S. Recent progress on biosorption of heavy metals from liquids using low cost biosorbents: Characterization, Biosorption Parameters and Mechanism Studies. Clean. 2008; 36(12): 937-962. doi:10.1002/clen.200800167. 
10. K.Suresh Kumar, Hans-UweDahms, Eun-JiWon, Jae-SeongLee, Kyung-HoonShin. Microalgae - A promising tool for heavy metal remediation. Ecotoxicol. Environ. Saf. 2015; 113:329-352. doi.org/10.1016/j.ecoenv.2014.12.019

11. Yabanli, M., Yozukmaz, A., Sel, F. (2014). Heavy metal accumulation in the leaves, stem and root of the invasive submerged macrophyte Myriophyllum spicatum L.(Haloragaceae): an example of Kadin Creek (Mugla, Turkey). Brazilian Archives of Biology and Technology. 2014; 57(3), 434-440. doi.org/10.1590/S1516-8913201401962

12. Kara Y. Bioaccumulation of nickel by aquatic macrophytes. Desal Water Treat. 2010; 19: 325-328. doi.org/10.5004/dwt.2010.1969

13. Fawzy MA, El-sayed Badr N, El-Khatib A, Abo-El-Kassem A. Heavy metal biomonitoring and phytoremediation potentialities of aquatic macrophytes in River Nile. Environ Monit Assess. 2011; 184(3):1753-1771. doi.org/10.1007/s10661-011-2076-9

14. Su Y, Liu H, Yang J. Metals and metalloids in the water-bloomforming cyanobacteria and ambient water from Nanquan coast of Taihu Lake, China. Bull Environ Contam Toxicol. 2012; 89:439-443. doi:10.1007/s00128-012-0666-z

15. Paéz-Espino D, Tamames J, Lorenzo V, Cánovas. Microbial responses to environmental arsenic. Biometals. 2009; 22:117-130. doi:10.1007/s10534-008-9195-y

16. Wilde W.E., Benemann J.R. Bioremoval of heavy metals by the use of microalgae. Biotechnol. Adv. 1993;11 (4):781-812. doi.org/10.1016/0734-9750(93)90003-6.

17. Franco MW, Ferreira FAG, Vasconcelos IF, Batista BL, Pujoni DG, Magalhães SMS, Barbosa F. Jr, Barbosa FA. Arsenic biotransformation by cyanobacteria from mining areas: evidences from culture experiments. Environ Sci Pollut R. 2015; 22(23): 18607-18615. doi: $10.1007 / \mathrm{s} 11356-015-5425-3$

18. Huang W-J, Wu C-C, Chang W-C. Bioaccumulation and toxicity of arsenic in cyanobacteria cultures separated from a eutrophic reservoir. Environ Monit Assess. 2014; 2:805-814. doi:10.1007/s10661-013-3418-6

19. Wang Z, Luo Z, Yan C. Accumulation, transformation, and release of inorganic arsenic by the freshwater cyanobacterium Microcystis aeruginosa. Environ Sci Pollut Res. 2013; 20:7286-7295. doi:10.1007/s11356-013-1741-7

20. Guo P, Gong Y, Wang C, Liu X, Liu J. Arsenic Speciation and Effect of Arsenate Inhibition in a Microcystis Aeruginosa Culture Medium under Different Phosphate Regimes. Environ Toxicol Chem. 2011; 30(8): 1754-9. doi:10.1002/etc.567.

21. Bhattacharya P, Pal R. Response of Cyanobacteria to Arsenic Toxicity. J Appl Phycol. 2010; 23(2): 293-299. doi:10.1007/s10811-010-9617-4.

22. Haheen R, Mahmud R, Sen J. A Study on Arsenic Decontaminating Cyanobacteria of an Arsenic Affected Soil. J Soil Nature. 2007; 1(2): 23-29.

23. Mur LR, Skulberg OM, Utkilen H. Cyanobacteria in The Environment. In: Chorus I, Bartram J. Toxic cyanobacteria in water. Londres: E \& FN Spon. 1999; 1: p.15-37.

24. Reire-Nordi CS, Vieira AAH, Nascimento OR. The Metal Binding Capacity of Anabaena spiroides Extracellular Polysaccharide: An EPR Study. Process Biochem. 2005; 40(6): 22152224. doi:10.1016/j.procbio.2004.09.003.

25. Pal A, Paul AK. Microbial Extracellular Polymeric Substances: Central Elements in Heavy Metal Bioremediation. Indian J Microbiol. 2008; 48(1): 49-64. doi:10.1007/s12088-0080006-5.

26. OECD Guideline 201. 2006. Freshwater alga and cyanobacteria, growth inhibition test. Organization for Economic Co-operation and Development, Paris. doi:10.1787/9789264069923-en

27. Barra CM, Santelli RE, Abrão JJ, Guardia M. Arsenic speciation - a review. Quim Nova. 2000; 23: 01-13. doi.: 10.1590/S0100-40422000000100012.

28. Srivastava AK, Bhargava P, Thapar R, Rai LC. Differential Response of Antioxidative Defense System of Anabaena Doliolum under Arsenite and Arsenate Stress. J Basic Microb. 2009; 49: 63-72. doi:10.1002/jobm.200800301.

29. Gong Y, Yi AH, Bibo L, Sheng W, Zhi W, Jing HD et al. Effects of Inorganic Arsenic on Growth and Microcystin Production of a Microcystis Strain Isolated from an Algal Bloom in Dianchi Lake, China. Chinese Sci Bull. 2011; 56(22): 2337-2342. doi:10.1007/s11434-0114576-y. 
30. Pandey S, Rai R, Rai LC. Proteomics Combines Morphological, Physiological and Biochemical Attributes to Unravel the Survival Strategy of Anabaena Sp. PCC7120 under Arsenic Stress. J Proteomics. 2012; 75(3): 921-37. doi:10.1016/j.jprot.2011.10.011.

31. Rzymski P, Poniedzialek B, Niedzielski P, Tabaczewski P, Wiktorowicz K. Cadmium and lead toxicity and bioaccumulation in Microcystis aeruginosa. Front Environ Sci Eng. 2014; 8(3): 427-432. doi: 10.1007/s11783-013-0566-4

32. Liu Z, Shen J, Carbrey JM, Mukhopadhyay R, Agre P, Rosen BP. Arsenite Transport by Mammalian Aquaglyceroporins AQP7 and AQP9. P Natl Acad Sci USA. 2002; 99(9): 60538. doi:10.1073/pnas.092131899.

33. Rosen BP. Biochemistry of Arsenic Detoxification. FEBS Lett. 2002; 529: 86-92. doi:10.1016/S0014-5793(02)03186-1

34. Tanghe A, Dijck PV, Thevelein JM. Why Do Microorganisms Have Aquaporins?. Trends Microbiol. 2006; 14(2): 78-85. doi:10.1016/j.tim.2005.12.001.

35. Takahashi A, Kawakami H, Iwakiri K, Matsuto S. Some Characteristics of Arsenate Transport in a Marine Cyanobacterium Synechococcus sp. Appl Organomet Chem. 2001; 15(4): 291-298. doi:10.1002/aoc.144.

36. Basile A, Sorbo S, Pisani T, Paoli L, Munzi S, Loppi S. Bioacumulation and Ultrastructural Effects of $\mathrm{Cd}, \mathrm{Cu}, \mathrm{Pb}$ and $\mathrm{Zn}$ in the Moss Scorpiurum Circinatum (Brid.) Fleisch. \& Loeske. Environ Pollut. 2012; 166: 208-11. doi:10.1016/j.envpol.2012.03.018.

37. Mona S, Kaushik A. Chromium and cobalt sequestration using exopolysaccharides produced by freshwater cyanobacterium Nostoc linckia. Ecol Eng. 2015; 82: 121-125. doi: 10.1016/j.ecoleng.2015.04.037.

38. Sun F, Yan Y, Liao H, Bai Y, Xing B, Wu F. Biosorption of antimony(V) by freshwater cyanobacteria Microcystis from Lake Taihu, China: effects of $\mathrm{pH}$ and competitive ions. Environ Sci Pollut Res Int. 2014; 21: 5836-5848. doi: 10.1007/s11356-014-2522-7

39. Prasad KS, Srivastava P, Subramanian V, Paul J. Biosorption of As(III) Ion on Rhodococcus sp. WB-12: Biomass Characterization and Kinetic Studies. Separ Sci Technol. 2011; 46(16): 2517-2525. doi:10.1080/01496395.2011.597040.

40. Aryal M, Ziagova M, Liakopoulou-Kyriakides M. Study on Arsenic Biosorption Using Fe (III) -Treated Biomass of Staphylococcus Xylosus. Chem Eng J. 2010; 162(1): 178-185. doi:10.1016/j.cej.2010.05.026.

41. Jiang G, Gong Z, Li XF, William R, Cullen WR, Le XC. Interaction of Trivalent Arsenicals with Metallothionein. Chem Res Toxicol. 2003; 16(7): 873-80. doi:10.1021/tx034053g. 